\title{
Genetic variability for grain yield and water use efficiency in blackgram genotypes
}

\author{
N. Jyothi Lakshmi*, M. Vanaja, S. K. Yadav, Amol Patil, Ch. Ram Prasad, P. Sathish, \\ Vijay Kumar, Vagheera, K. Salini and M. Maheswari
}

Central Research Institute for Dryland Agriculture, Hyderabad (Telangana), INDIA

*Corresponding author. E-mail: lakshmi.jyothi70@gmail.com

Received: December 21, 2016; Revised received: April 8, 2017; Accepted: August 5, 2017

\begin{abstract}
Transpiration efficiency (TE, g biomass $\mathrm{kg}^{-1}$ water transpired) is the preferred measure for examining potential genetic variation in crop water use efficiency (WUE). TE was assessed gravimetrically from sowing to grain harvest in fifteen blackgram accessions, two checks and two local varieties under well-watered conditions during kharif season. $\mathrm{TE}_{\text {biomass }}$ varied from $2.87-5.27 \mathrm{~g} \mathrm{~kg}^{-1}$ and $\mathrm{TE}_{\text {seed }}$ varied from $1.10-2.03 \mathrm{~g} \mathrm{~kg}^{-1}$ among genotypes.

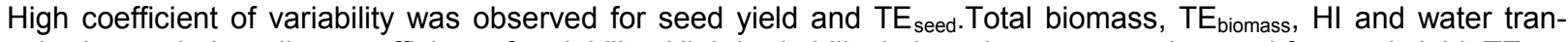
spired recorded medium coefficient of variability. High heritability in broad sense was observed for seed yield, $\mathrm{TE}_{\text {seed }}$ and total biomass. High genetic advance as percent of mean was observed for seed yield, $\mathrm{TE}_{\text {seed, }}$ total biomass and $\mathrm{TE}_{\text {biomass. }}$ High heritability coupled with high genetic advance as per cent of mean was observed for seed yield, total biomass and $T E_{\text {seed. }} T E_{\text {seed }}$ is significantly positively correlated with $\mathrm{TE}_{\text {biomass }}\left(0.883^{* *}\right)$, seed yield $/$ plant $\left(0.805^{* *}\right), \mathrm{HI}$ $\left(0.757^{* *}\right)$ and biomass $\left(0.572^{*}\right)$. TE $E_{\text {biomass, }}$ seed yield per plant, total biomass and $\mathrm{HI}$ were the important components of $\mathrm{TE}_{\text {seed }}$ as revealed by correlation studies. $\mathrm{D}^{2}$ analysis partitioned the nineteen genotypes in to five clusters. The maximum inter cluster distance was observed between cluster II and V (24.94) and III and IV (22.6). Genotypes IC436665, IC343952 and Local II (Cluster III) had high mean values for TE $\mathrm{b}_{\text {biomass }}$ and $\mathrm{TE}_{\text {seed }}$ along with total biomass and seed yield. These genotypes should be useful in future breeding programs for higher water use efficiency.
\end{abstract}

Keywords: Blackgram, Cluster analysis, Heritability, Water use efficiency

\section{INTRODUCTION}

The ability of crop to produce high yield per unit of available water is potentially important in affecting profitability and yield, in both irrigated and rainfed production systems. Genetically increasing crop water use efficiency is an effective strategy for increasing yield in dry environments (Condon et al., 2004; Blum 2009) as forecasts of increasing scarcity of water for agriculture remains a strong motivation for improving crop water use efficiency. Transpiration efficiency (TE) defined as the biomass production per unit of water transpired is the preferred measure for examining potential genetic variation in crop water use efficiency (WUE). Transpiration efficiency is WUE of plants alone (no soil water losses).

Almost a century ago, Briggs and Shantz (1913) showed that crop species differ in their transpiration efficiency. Since then, the $\mathrm{C}_{3}$ and $\mathrm{C}_{4}$ photosynthetic pathways have been elucidated, and differences in transpiration efficiency have been related to them. Subsequent studies have identified genetic variation in transpiration efficiency within a species, example include groundnut (Ratnakumar et al.,2009, Halilou et al., 2015), cowpea (Ismael and Hall 1992, Halilou et al., 2015), wheat (Farquhar and Richards 1984, Blum 2009) and sorghum (Hammer et al., 1997, Xin et al., 2009) and breeding efforts have been made to include $\mathrm{TE}$ in the improved germplasm (Udayakumar et al., 1998).Blackgram is one of the important short duration pulse crop fits into any cropping system of rainfed areas. Genotypic variation for biomass and grain yield in blackgram genotypes obtained from NBPGR Regional Centre, Hyderabad has been reported (Babu Abrahamet al.,2013 and Vijay kumar et al. 2014). Therefore differences in water requirement might surely exist in these blackgram genotypes, but no accurate estimation of the water requirement is reported (Vijay kumar et al. 2014). The present investigation was undertaken with a view to quantify the genetic variation for water use and $\mathrm{TE}$ in blackgram genotypes (obtained from NBPGR Regional Centre, Hyderabad), to estimate genetic variance, heritability and genetic advance and to investigate the nature and magnitude of genetic diversity in 19 blackgram genotypes.

\section{MATERIALS AND METHODS}

Fifteen blackgram genotypes obtained from NBPGR Regional Centre, Hyderabad which were originally 
collected from different agro-climatic zones of Telangana and Andhra Pradesh statesviz.,IC587753, IC436720, IC436519, IC343947, IC519805, IC343952, IC587752, IC587751, IC282009, IC436753, IC436610, IC436665, IC398971, IC281987 and IC 436652, twonationally released varieties (LBG $-20, T-9)$ and two local varieties were evaluated to know the genotypic variations in water use and transpiration efficiency from sowing to grain harvest (during kharif in rainout shelter facility) and identify genotypes with high transpiration efficiency and harvest index (HI). The experiment was a completely randomized block design with nineteen genotypes and three replications. Growth observations and water balance in pots quantified components of whole-plant TE.

Transpiration efficiency was determined by a high throughput gravimetric method (Xin et al., 2008) with modifications. Whole plant level TE was determined gravimetrically in 12 liter plastic pots filled with a mixture of red soil and farm yard manure. Recommended dose of fertilizer was used. Two seeds were planted per pot and thinned to one plant at $7 \mathrm{~d}$ after emergence. The pots were then covered from both ends with poly bags. A slit was cut in the top bag to permit seedling growth. The slit was further sealed with a piece of clear adhesive tape. The poly bags were tightly fixed onto the pots with an elastic band. The initial weight recorded. The pots were weighed every 3 days (from 7 days after covering with poly bags) and measured quantity of water was supplemented through a funnel placed into the poly bag and again sealed with tape after watering. When the plants reached maturity, they were harvested at soil level and final pot weight was recorded. Individually plants were partitioned into pods, leaves, and stems and the dry weight was recorded. Total water used was calculated by subtracting the final pot weight from the initial weight and then adding the amount of water that has been applied at regular intervals. $\mathrm{TE}_{\text {biomass }}$ was calculated by dividing the above ground dry biomass by the amount of water transpired; $\mathrm{TE}_{\text {seed }}$ was calculated by dividing the seed yield by the amount of water used.

Phenotypic and genotypic coefficients of variation (Burton, 1952), heritability in broad sense (Allard, 1960),genetic advance as percentage of mean (Johnson et al., 1955),phenotypic and genotypic correlations (Falconer, 1964) were estimated and categorized as per the standard statistical procedures.Diversity analysis was done as per Mahalanobis's $D^{2}$ statistics and grouping was done based on Tocher's method (Rao,1952).

\section{RESULTS AND DISCUSSION}

There was significant genetic variation for all traits measured on a whole plant basis in blackgram genotypes (Table1). Phenotypic values for $\mathrm{TE}_{\text {biomass }}$ and $\mathrm{TE}_{\text {seed }}$ ranged from 2.87 to $5.27 \mathrm{~g} / \mathrm{kg}$ and 1.10 to $2.15 \mathrm{~g} /$ $\mathrm{kg}$ respectively. These values are in accordance with the WUE range reported for $\mathrm{C}_{3}$ crops such as groundnut (Ratnakumar et al., 2009, Halilou et al., 2015). Wide range of variation was observed for most of the characters which indicated wide genetic diversity among the genotypes under study. Presence of wide spectrum of variability would enhance the chance of selecting desirable genotypes. The observed variability in the character may either be due to genotypic or environmental factors. Hence, it is essential to partition the observed variability into heritable and non heritable components by studying genotypic and phenotypic coefficients of variation. Phenotypic coefficient of variation was higher than genotypic coefficient of variation for all the characters which means that apparent variation was not only due to genotypes but also due to the influence of environment. However, narrow difference between genotypic and phenotypic coefficients of variation estimates indicated little influence of environment on the expression of these traits and variability was mainly due to genetic constitution. This implied phenotypic variability to be a reliable measure of genotypic variability.

Phenotypic and genotypic coefficients of variation ranged from 13.08 and 9.10 (HI) to 27.03 and 21.93 per cent (seed yield) respectively (Table 2 ). High coefficient of variability was observed for seed yield which indicated high variability for this character among the genotypes and there is a great scope for improvement of these characters by direct selection among the genotypes.High PCV for seed yield and plant biomass was also reported earlier by Vijay et al. (2015). Medium variability was observed for the remaining characters indicated variation for these characters was medium among the genotypes and there is a need for improvement of base population to increase the genetic variability and to fix the favourable alleles. For assessing the heritable variation, the magnitude of heritability is the most important aspect in the breeding material which has close bearing on the response to selection. Estimates of heritability ranged from 48.26 (water transpired) to 65.82 per cent (seed yield) (Table 2).High heritability in broad sense were observed for seed yield, $\mathrm{TE}_{\text {seed }}$ and total biomass which indicated that these characters were relatively less influenced by environmental conditions and phenotypic selection would be effective for the improvement of these characters. Previously, high heritability for seed yield and total biomass has also been reported in blackgram by Deepshikha et al. (2014).

Genetic advance as per cent of mean ranged from 13.02 (harvest index) to 36.65 per cent (seed yield) (Table 2).High genetic advance as per cent of mean was observed for seed yield, $\mathrm{TE}_{\text {seed, }}$ total biomass and $\mathrm{TE}_{\text {biomass }}$ which indicated that these characters were governed by additive gene action and selection would be effective for improvement of these characters. Harvest index and water transpired showed medium genet- 
Table 1. Analysis of variance for six characters in blackgram.

\begin{tabular}{lccccccc}
\hline Source & df & $\begin{array}{c}\text { Total } \\
\text { biomass }\end{array}$ & Seed Yield & HI & $\begin{array}{c}\text { Water Tran- } \\
\text { spired }\end{array}$ & TE $_{\text {biomass }}$ & TE $_{\text {seed }}$ \\
\hline Replications & 2 & 2.355 & 1.080 & 21.02 & 0.057 & 0.031 & 0.064 \\
Genotypes & 18 & $13.635^{* *}$ & $3.238^{* *}$ & $45.34^{* *}$ & $0.467^{* *}$ & $0.915^{* *}$ & $0.272^{* *}$ \\
Error & 36 & 2.417 & 0.478 & 11.91 & 0.123 & 0.173 & 0.041 \\
SEm & & 0.897 & 0.399 & 1.993 & 0.202 & 0.240 & 0.116 \\
CV (\%) & & 13.08 & 15.80 & 9.40 & 11.27 & 10.83 & 14.21 \\
CD (5\%) & & 2.57 & 1.14 & 5.71 & 0.580 & 0.688 & 0.333 \\
\hline
\end{tabular}

Table 2.Summary results of key traits in blackgram genotypes.

\begin{tabular}{clcccccc}
\hline S.No & \multicolumn{1}{c}{ Character } & Range & Mean & PCV (\%) & $\begin{array}{c}\text { GCV } \\
\text { (\%) }\end{array}$ & $\mathbf{h}^{2}(\%)$ & $\begin{array}{c}\text { GA as \%of } \\
\text { mean }\end{array}$ \\
\hline 1. & Total biomass $(\mathrm{g} / \mathrm{pl})$ & $8.29-16.99$ & 11.88 & 20.89 & 16.28 & 60.74 & 26.13 \\
2. & Seed Yield $(\mathrm{g} / \mathrm{pl})$ & $2.95-6.89$ & 4.37 & 27.03 & 21.93 & 65.82 & 36.65 \\
3. & Harvest Index (\%) & $26.75-42.42$ & 36.70 & 13.08 & 9.10 & 48.32 & 13.02 \\
4. & Water Transpired $(\mathrm{kg} / \mathrm{pl})$ & $2.28-3.91$ & 3.11 & 15.67 & 10.89 & 48.26 & 15.58 \\
5. & $\mathrm{TE}_{\text {biomass }}\left(\mathrm{g} \mathrm{kg}^{-1}\right)$ & $2.87-5.27$ & 3.84 & 16.89 & 12.96 & 58.86 & 20.48 \\
6. & $\mathrm{TE}_{\text {seed }}\left(\mathrm{g} \mathrm{kg}^{-1}\right)$ & $1.10-2.15$ & 1.42 & 24.22 & 19.61 & 65.57 & 32.71 \\
\hline
\end{tabular}

Table 3. Per cent contribution of characters towards diversity in blackgram genotypes.

\begin{tabular}{|c|c|c|c|}
\hline S.No. & Character & Times Ranked $1^{\text {st }}$ & Per cent contribution \\
\hline 1. & Total biomass $(\mathrm{g} / \mathrm{pl})$ & 38 & 22.22 \\
\hline 2. & Seed yield $(\mathrm{g} / \mathrm{pl})$ & 14 & 8.19 \\
\hline 3. & Harvest Index (\%) & 10 & 5.85 \\
\hline 4. & Water Transpired $(\mathrm{kg} / \mathrm{pl})$ & 24 & 14.04 \\
\hline 5. & $\mathrm{TE}_{\text {biomass }}\left(\mathrm{g} \mathrm{kg}^{-1}\right)$ & 29 & 16.96 \\
\hline 6. & $\mathrm{TE}_{\text {seed }}\left(\mathrm{g} \mathrm{kg}^{-1}\right)$ & 56 & 32.75 \\
\hline
\end{tabular}

ic advance which indicated that these characters were governed by both additive and non additive gene actions and selection might prove ineffective for the improvement of this character. High heritability coupled with high genetic advance as per cent of mean was observed for seed yield, total biomass and $\mathrm{TE}_{\text {seed }}$ which indicated that most likely the high heritability might be due to additive gene effects hence; it could be improved by simple selection methods like pureline selection, mass selection, progeny selection or family selection. The results are in conformity with the findings of Deepshikha et al. (2014) and Vijay et al. (2014) for seed yield per plant and total biomass.

As indicated by GCV, genetic variation was high for seed yield $(21.93 \%)$ and medium for total biomass (16.28) and water transpired (10.89\%) which are components of TE (Table 2). However, there was proportionally less genetic variation for $\mathrm{TE}_{\text {biomass }}(12.96 \%)$ and $\mathrm{TE}_{\text {seed }}(19.61 \%)$ as compared to individual components, as indicated by the smaller genetic CV for this trait compared with the two components of this ratio. Harvest index ranged from 26.75 to $42.42 \%$ with a mean of $36.7 \%$. GCV was low for HI $(9.10 \%)$ and low $\mathrm{GCV}$ of this character can be due to medium variation in total biomass inspite of high variation in seed yield.
Broad sense heritabilities were high $(>60 \%)$ for the characters viz., total biomass, seed yield and $\mathrm{TE}_{\text {seed }}$ and it was medium for HI, water transpired and $\mathrm{TE}_{\text {biomass. }}$ Knowledge about the nature and extent of association among different biometrical characters will be useful to identify the key characters for which selection can be fruitfully made. High magnitude of genotypic correlations indicated that there was a strong inherent genetic association between the various characters studied. $\mathrm{TE}_{\text {seed }}$ is significantly positively correlated with $\mathrm{TE}_{\text {bio- }}$ mass $\left(0.883^{* *}\right)$, seed yield per plant $\left(0.805^{* *}\right)$, HI $\left(0.757^{* *}\right)$, and biomass $\left(0.572^{*}\right)$ (Fig. 1$)$. Grain yield is significantly correlated with total biomass $\left(0.883^{* *}\right)$, HI $\left(0.662^{* *}\right)$, TE biomass $\left(0.697^{* *}\right)$ (Fig. 1$)$. Water transpired is highly correlated with biomass $\left(0.596^{*}\right)$ and negatively with $\mathrm{TE}_{\text {seed }}(-0.213)$. Similar positive and significant correlation of seed yield with total biomass and HI were reported in blackgram by Vijay et al. (2015).Correlation among component characters revealed that strong positive associations among desirable component characters, hence selection criteria should consider all these characters.

Multivariate analysis using Mahalanobis $\mathrm{D}^{2}$ statistic provides a useful tool for measuring the genetic diversity with respect to all the characters considered to- 
Table 4. Grouping of nineteen black gram genotypes based on $\mathrm{D}^{2}$ analysis.

\begin{tabular}{ccl}
\hline Cluster & No. of genotypes & \multicolumn{1}{c}{ Genotypes } \\
\hline I & 11 & IC436610, LOCAL -1, IC282009, IC587751, IC281987, IC436652, IC398971, \\
II & 3 & IC343947, IC519805, IC436519, IC436753 \\
III & 3 & IC436720, LBG-20, IC58775 \\
IV & 1 & IC436665, LOCAL -II, IC343952 \\
V & 1 & IC587752 \\
\hline
\end{tabular}

Table 5. Average inter and intra cluster D values in 5 clusters of 19 blackgram genotypes.

\begin{tabular}{cccccc}
\hline Clusters & I & II & III & IV & V \\
\hline I & 1.81 & 4.50 & 10.66 & 8.84 & 15.48 \\
II & & 1.01 & 19.15 & 9.87 & 24.94 \\
III & & 6.79 & 22.59 & 18.38 \\
IV & & & 0.00 & 17.21 \\
V & & & & 0.00 \\
\hline
\end{tabular}

Table 6. Cluster means for six characters in 19 blackgram genotypes.

\begin{tabular}{ccccccc}
\hline Clusters & $\begin{array}{c}\text { Total } \\
\text { biomass }\end{array}$ & Seed yield & HI & $\begin{array}{c}\text { Water } \\
\text { transpired }\end{array}$ & TE $_{\text {biomass }}$ & $\mathbf{T E}_{\text {seed }}$ \\
\hline I & 11.18 & 3.98 & 35.58 & 2.99 & 3.75 & 1.34 \\
II & 10.68 & 3.97 & 37.39 & 3.39 & 3.13 & 1.17 \\
III & 15.68 & 6.49 & 41.51 & 3.40 & 4.64 & 1.92 \\
IV & 13.41 & 3.61 & 26.75 & 3.57 & 3.92 & 1.08 \\
V & 10.27 & 4.37 & 42.43 & 2.28 & 4.49 & 1.90 \\
\hline
\end{tabular}

gether. Analysis of variance for dispersion showed highly significant mean sum of squares due to genotypes. Test of significance using Wilk's criterion revealed highly significant $\mathrm{V}$ statistics. The $\mathrm{D}^{2}$ values were computed for all possible pairs of combinations from the mean values of 19 genotypes for 6 characters. Ranking character wise $\mathrm{D}^{2}$ values and adding the ranks for each character for all the genotypes had done to identify the characters that contributed maximum towards divergence. Contribution of different characters towards genetic divergence is presented in Table 3. $\mathrm{TE}_{\text {seed }}$ showed highest contribution of $32.75 \%$ followed by total biomass $(22.22 \%)$, $\mathrm{TE}_{\text {biomass }}(16.96 \%)$ and water transpired (14.04\%).High \% contribution of these characters towards genetic diversity indicated these characters can be used as parameters in selecting genetically diverse parents for hybridization.

Nineteen genotypes were grouped in to 5 clusters. The compositions of different clusters along with number of genotypes are given in Table 4. Cluster I was the largest with 11 genotypes and II and III with three genotypes each and remaining clusters were solitary. Presence of solitary clusters indicated the extreme phenotypic performance in positive or negative directions for one or the other character included in the present study. Random pattern of distribution of accessions into various clusters from different eco-geographic regions revealed that there was no parallelism between genetic diversity and geographic diversity. The nature of selection forces operating under one ecogeographical region seemed to be similar to that of other regions since the accessions from different geographical regions were grouped together into same clusters. This would be due to the similarity of objectives and conditions under which the types were bred and domesticated in different localities. By observing the cluster composition, it was evident that accessions of same geographical origin (Telengana and Andhra Pradesh) were scattered into four different clusters. The existence of wide genetic diversity among the accessions chosen from the same geographical region was thus obvious. The wide divergence noticed might also be indicative of crop adaptation for wide environmental conditions under which this crop was grown. Inter and intra cluster genetic distance (D) values among five clusters are presented in Table 5. Inter cluster D values ranged from 4.50 (I and II) to 24.94 (II and V). High inter cluster distance between cluster II and V and III and IV suggested genotypes belonging to the clusters separated by high statistical distance could be used in recombination breeding for obtaining high heterotic responses and better segregants.

Intra cluster values ranged from 0 to 6.78 . Maximum intra cluster distances were recorded by cluster III indicated these cluster had the accessions with varied genetic divergence while accessions of clusters I and II showing minimum intra cluster distance genetically resembled to each other and might have come from 

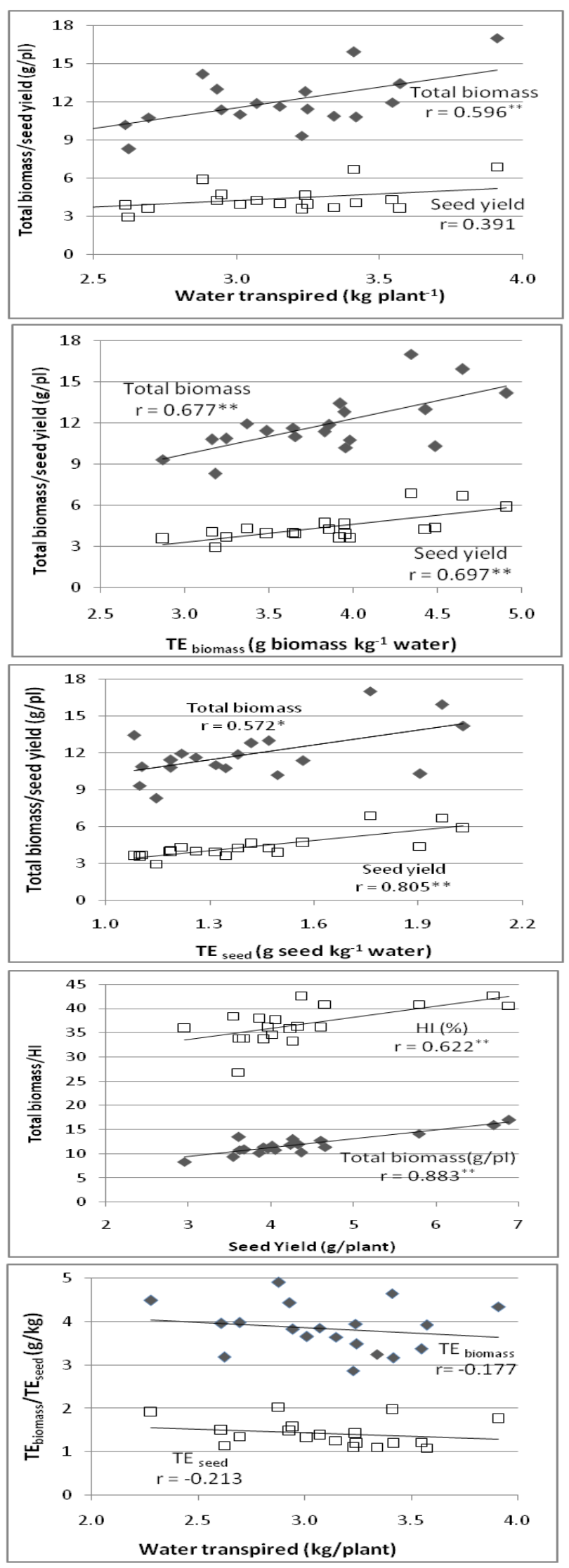

Fig 1. Correlation between various parameters in blackgram genotypes. common gene pool. Intra cluster distances were zero in the solitary clusters.

Cluster mean values were given in Table 6. Total biomass ranged 10.27 (V) to $15.68 \mathrm{~g} / \mathrm{pl}$ (III). Seed yield ranged from 3.61 (IV) to $6.49 \mathrm{~g} / \mathrm{pl}$ (III). Harvest index ranged from 26.75 (IV) to $42.43(\mathrm{~V})$. Water transpired ranged from $2.28(\mathrm{~V})$ to $3.57 \mathrm{Kg} / \mathrm{pl}(\mathrm{IV})$. Biomass ranged from 3.13 (II) to $4.64 \mathrm{~g} / \mathrm{kg}$ (III). TE seed ranged from 1.08 (IV) to $1.91 \mathrm{~g} / \mathrm{kg}$ (III).

\section{Conclusion}

There was significant difference between genotypes for all the characters studied. Seed yield showed high variability, heritability and genetic advance as per cent of mean which indicated additive gene action for the expression of this character and scope of simple selection for improvement of this character. $\mathrm{TE}_{\text {biomass, }}$ seed yield per plant, total biomass and HI were the important components and due weightage should be given on these characters in selection programme for $\mathrm{TE}_{\text {seed }}$. T-9 (cluster V) with high $\mathrm{TE}_{\text {biomass }}$ and $\mathrm{TE}_{\text {seed }}$ transpired low amount of water is having low biomass. Cluster III (IC436665, IC343952 and Local II) had high mean values for total biomass( $15.68 \mathrm{~g} / \mathrm{pl})$, seed yield $(6.49 \mathrm{~g} / \mathrm{pl}), \mathrm{TE}_{\text {biomass }}(4.64 \mathrm{~g}$ biomass $/ \mathrm{kg}$ water transpired) and $\mathrm{TE}_{\text {seed }}(1.92 \mathrm{~g} \mathrm{seed} / \mathrm{kg}$ water transpired $)$ and for harvest index (41.5\%) and water transpired $(3.40 \mathrm{~kg} / \mathrm{plant})$ this cluster was ranking second. Selection of genotypes can be done from this cluster for best combination of these characters. Divergent parents can be selected from cluster III and IV and II and V.

\section{REFERENCES}

Allard R.W. (1960). Principles of plant breeding. John Wiley and Sons Inc., U.S.A.

Babu Abraham, Vanaja M., Reddy P. Raghu Ram, Sivaraj N., Sunil N.,Kamala V., and K.S. Varaprasad. (2013). Identification of stable and high yielding genotypes in blackgram (Vigna mungo (L.) Hepper) germplasm. Indian Journal of Genetics and Plant Breeding, 73 (3):264-269.

Blum A. (2009). Effective use of water (EUW) and not water -use efficiency (WUE) is the target of crop yield improvement under drought stress. Field Crops Research,112: 119-123.

Briggs L. J, Shantz HL. (1913)The water requirement of plants. I. Investigations in the Great Plains in 1910 and 1911. United States Department of Agriculture, Bureau of Plant Industry, Bulletin No. 284, 49 pp.

Burton G.W. (1952) Quantitative inheritance in grasses. In: Proc. of the $6^{\text {th }}$ International Grassland Congress, pp 277-283.

Condon AG, Richards RA, Rebetzke GJ, Farqhuar GD. 2004. Breeding for high water use efficiency. Journal of Experimental Botany 55,2447-2460.

Deepshikha , Roopa lavanya G and Sujeet kumar.(2014) Assessment of genetic variability for yield and its contributing traits in Blackgram. Trends in biosciences 7 (18): 2835-38. 
Falconer D.S. (1964) An Introduction to Quantitative Genetics - Second edition. Oliver and Boyd Ltd., Edinburgh pp. 312-324.

Farquhar GD, Richards RA. Isotope Composition of Plant Carbon Correlates with Water-use Efficiency of Wheat Genotypes. Australian Journal of Plant Physiology,11: 539-552.

Hammer G.L., Farquhar G.D., and I. Broad. (1997) On the extent of genetic variation fortranspiration efficiency in sorghum. Australian Journal of Agricultural Research, 48:6349-655.

Halilou O., HamidouF, Taya B. K, Mahamane S and Vadez V. (2015)Water use, transpiration efficiency and yield in cowpea (vigna unguiculata) and peanut (Arachis hypogaea) across water regimes. Crop and Pasture Science, 66(7):715-728

Ismael A.M., Hall A.E. (1992) Correlation between wateruse efficiency and carbon isotope discrimination in diverse cow- pea genotypes and isogenics lines. Crop Science, 32: 7-12.

Johnson, H.W., H.F. Robinson and R.E. Comstock. (1955) Estimates of genetic and environmental variability in soybean. Agronomy Journal, 47: 314-318.

Rao, C.R. (1952) Advanced Statistical methods in Biometrical Research. John Wiley and Sons, Inc. New York: 357-363

Ratnakumar P, Vadez V, Nigam S, Krishnamurthy L. (2009) Assessment of transpiration efficiency in peanut (Arachis hypogaea L.) under drought using a lysimetric system. Plant Biology,11: 124-130.

Udayakumar M., Sheshshayee M.S., Nataraj K.N., Madhava H.B., Devendra R., Aftab Husssain I.S., Prasad T.G. (1998) Why has breeding for water-use efficiency not been success-ful? An analysis and alternate approach to exploit this trait for crop improvement. Current Science, 74: 99-100.

Vijay Kumar G, Vanaja M, Raghu Ram Reddy P, Salini K, Babu Abraham and N Jyothi Lakshmi. (2014) Studies on combining ability and genetic advance in blackgram (Vigna mungo L. Hepper) under rainfed condition.Research and Reviews: Journal of Agriculture and Allied Sciences, 3(3):14-24.

Vijay Kumar G, Vanaja M, Babu Abrahum, Anitha Y, Jyothi Lakshmi N. and M.Maheswari.(2015) Variability, heritability and genetic advance for quantitative traits in blackgram (Vigna mungo (L.) Hepper). International Journal of Current Science, 17: E 37-42.

Vijay Kumar G, Vanaja M, Sathish P,Vagheera P and N. Jyothi Lakhsmi. (2015)Correlation analysis for quantitative traits in blackgram (Vigna mungo (L.) Hepper) in different seasons. International Journal of Scientific and Research Publications, 5(4):01-10

Xin, Z., Franks, C., Payton, P., Burke, J.J. (2008) A simple method to determine transpiration efficiency in sorghum.Field Crops Research 107: 180-183.

Xin Z, Aiken R, Burke J. (2009) Genetic diversity of transpiration efficiency in sorghum. Field Crops Research 111: $74-80$. 